\title{
RISIKO LINGKUNGAN FISIK TERHADAP KEJADIAN MALARIA DI WILAYAH DANAU SENTANI, KABUPATEN JAYAPURA, PROVINSI PAPUA (Physical Environment Risk to The Incidence of Malaria in The Region of Sentani Lake, Jayapura District, Papua Province)
}

\author{
Abner Fritz Watofa ${ }^{1 *}$, Adi Heru Husodo ${ }^{2}$, Sudarmadji ${ }^{3}$ dan Onny Setiani ${ }^{4}$ \\ ${ }^{1}$ Fakultas Kesehatan Masyarakat Universitas Cendrawasih Papua, \\ Jl. Sentani Abepura, Jayapura 99221. \\ ${ }^{2}$ Fakultas Kedokteran Universitas Gadjah Mada Yogyakarta, \\ J1. Farmako Bulaksumur Yogyakarta 55281. \\ ${ }^{3}$ Fakultas Geografi Universitas Gadjah Mada Yogyakarta, \\ Jl. Kaliurang Bulaksumur Yogyakarta 55281. \\ ${ }^{4}$ Fakultas Kesehatan Masyarakat Universitas Diponegoro Semarang \\ J1. Profesor Subarda, SH Semarang 50275.
}

*Penulis korespondensi. Tel: 081227485888. Email: abnerfritzwatofa@yahoo.com.

\begin{abstract}
Abstrak
Kejadian malaria di Indonesia merupakan persoalan kesehatan yang utama. Di Provinsi Papua, khususnya di wilayah Danau Sentani, prevalensi kejadian malaria masih menunjukkan angka yang tinggi. Kejadian ini dipengaruhi oleh berbagai faktor di antaranya adalah faktor lingkungan fisik. Untuk mengetahui dan menganalisis hubungan antara faktor risiko lingkungan fisik yang terdiri dari suhu, kelembaban, curah hujan, kondisi air, ketinggian, lahan, dan kondisi tempat tinggal dengan kejadian malaria di wilayah Danau Sentani. Observasi analitik yang dilaksanakan di empat kampung di wilayah Distrik Sentani Kabupaten Jayapura yaitu Kampung Yoboi/Kehiran, Kampung Hobong, Ifar Besar, dan Ifale. Populasi dalam penelitian ini adalah seluruh penduduk di Distrik Sentani. Sampel penelitian sebanyak 200 orang. Teknik pengambilan sampel dilakukan secara random. Metode pengumpulan data dengan cara kuesioner, observasi, dokumentasi, dan wawancara. Metode analisis menggunakan analisis bivariate, uji statistik Chi-Square, dan uji regresi logistik. Faktor lingkungan fisik memiliki hubungan yang bermakna dengan kajadian malaria, dengan nilai Chi-Square sebesar 7,531 ( $\mathrm{p}=0.006<0,05)$, rasio regresi logistik dengan nilai OR sebesar 4,132 $(\mathrm{p}=0,009>0,05)$. Lingkungan fisik yang terdiri dari suhu, kelembaban, curah hujan, kondisi air, ketinggian, lahan, dan kondisi tempat tinggal mempengaruhi kejadian malaria di wilayah Danau Sentani.
\end{abstract}

Kata kunci: curah hujan, kondisi air, kondisi tempat tinggal, malaria, suhu dan kelembaban.

\begin{abstract}
The incidence of malaria represented serious health problem in Indonesia. In Papua province, especially in the area of Sentani Lake, the prevalence of malaria was still high. It was influenced by various physical environmental factors. The study aimed at identifying and analyzing the correlation between physical environment and the incidence of malaria in the region of Sentani Lake. It was an observational and analytic study conducted in four villages in the area of Sentani district, Jayapura, which were Yoboi/Kehiran, Hobong, Ifar Besar and Ifale. Its population was all of the residents of Sentani district and there were 200 individuals randomly drawn as samples. Data were collected using questionnaires, observation, documentation, and interviews. The data were analyzed using bivariate analysis, ChiSquare statistic test, and logistic regression. The results showed that the physical environmental factors and the incidence of malaria were significantly correlated with the Chi-Square value of $7.531(p=0.006<0.05)$ and the regression ratio OR of $4.132(p=0.009>0.05)$. The physical environmental factors, including temperature, humidity, rainfall, water condition, elevation, and living condition, had significant influence on the incidence of malaria in Sentani Lake region.
\end{abstract}

Keywords: rainfall, water, living condition, temperature, humidity and malaria.

\section{PENDAHULUAN}

Kejadian malaria di Kabupaten Jayapura tidak merata. Dari 16 wilayah Puskesmas ditemukan kejadian malaria tertinggi di 3 Puskesmas yaitu Puskesmas Sentani Timur, Puskesmas Sentani dan Puskesmas Sentani barat dinyatakan sebagai daerah endemis malaria. Danau Sentani termasuk dalam 
wilayah Puskesmas Sentani dengan data sebagai berikut : pada tahun 2013 kasus malaria meningkat dengan Annual Parasite Incidence (API) 232 per 1000 penduduk, sedangkan kasus penyakit malaria turun menjadi 13,824 kasus (AMI 122 per 1000 penduduk).

Berpedoman pada realita tingginya kejadian malaria di wilayah Danau Sentani, maka ada beberapa penelitian terdahulu seperti Ayomi dkk (2012) tentang suhu di wilayah Danau Sentani yang masih dikatakan suhu normal yang sama dengan suhu-suhu di daerah lain di Indonesia karena merupakan suhu wilayah tropis yang ditekankan pada perbedaan suhu terendah sampai suhu tertinggi pada siang dan malam hari yang mempengaruhi perkembangbiakan nyamuk.

Selain itu penelitian yang hampir serupa dilakukan oleh Arsin dan Karim (2012) mengenai hubungan suhu dengan kejadian malaria di Halmareha Tengah yang mengukur suhu di wilayah tersebut rata-rata berkisar antara $26,8{ }^{\circ} \mathrm{C}$ sampai dengan $27{ }^{\circ} \mathrm{C}$ berpengaruh terhadap kejadian malaria.

Marrai (2006) melakukan penelitian terkait faktor-faktor yang berhubungan dengan dinamika penularan penyakit malaria falciparum di Kecamatan Nabire Kota. Penelitiannya menggunakan metode Cross Sectional. Berdasarkan hasil penelitiannya dapat diketahui bahwa terdapat hubungan antar kondisi lingkungan, kondisi penduduk, dan keberadaan vektor dengan kejadian penyakit malaria (falciparum) di Kecamatan Nabire Kota.

Perubahan unsur-unsur cuaca berpengaruh terhadap vektor penyakit. Peningkatan suhu, kelembaban dan curah hujan terbukti diikuti dengan peningkatan kasus malaria yang terjadi di Srilangka dan Punjab. Perbedaan karakteristik wilayah berpengaruh terhadap perbedaan cuaca, sehingga populasi vektor di satu wilayah yang berbeda karakteristiknya akan berbeda pula kepadatannya (Raharjo, 2003; Kumar dkk., 2014).

Di wilayah Danau Sentani kejadian malaria masih tergolong tinggi. Penelitian ini bertujuan untuk mengetahui pengaruh faktor lingkungan fisik terhadap kejadian malaria di wilayah Danau Sentani.

\section{METODE PENELITIAN}

\section{Waktu dan Lokasi}

Penelitian ini dilaksanakan selama 6 bulan (April-November 2013). Lokasi penelitian adalah empat kampung di wilayah Distrik Sentani Kabupaten Jayapura yaitu Kampung Yoboi/Kehiran, Hobong, Ifar Besar, dan Ifale (Gambar 1) dengan pendekatan penelitian crosssectional dengan jenis penelitian observasi analitik yang menjadi sampel penelitian adalah seluruh penduduk di Distrik Sentani dengan sampel penelitian sebanyak 200 orang. Teknik pengambilan sampel secara random.

\section{Prosedur}

Metode pengumpulan data lingkungan fisik yang terdiri dari suhu, curah hujan, $\mathrm{pH}$ air, kelembaban tanah dan udara, ketinggian dan penggunaan lahan, dilakukan dengan cara kuesioner, observasi, dokumentasi, dan wawancara. Data tersebut kemudian dianalisis menggunakan analisis bivariate, uji statistik Chi-Square, dan uji

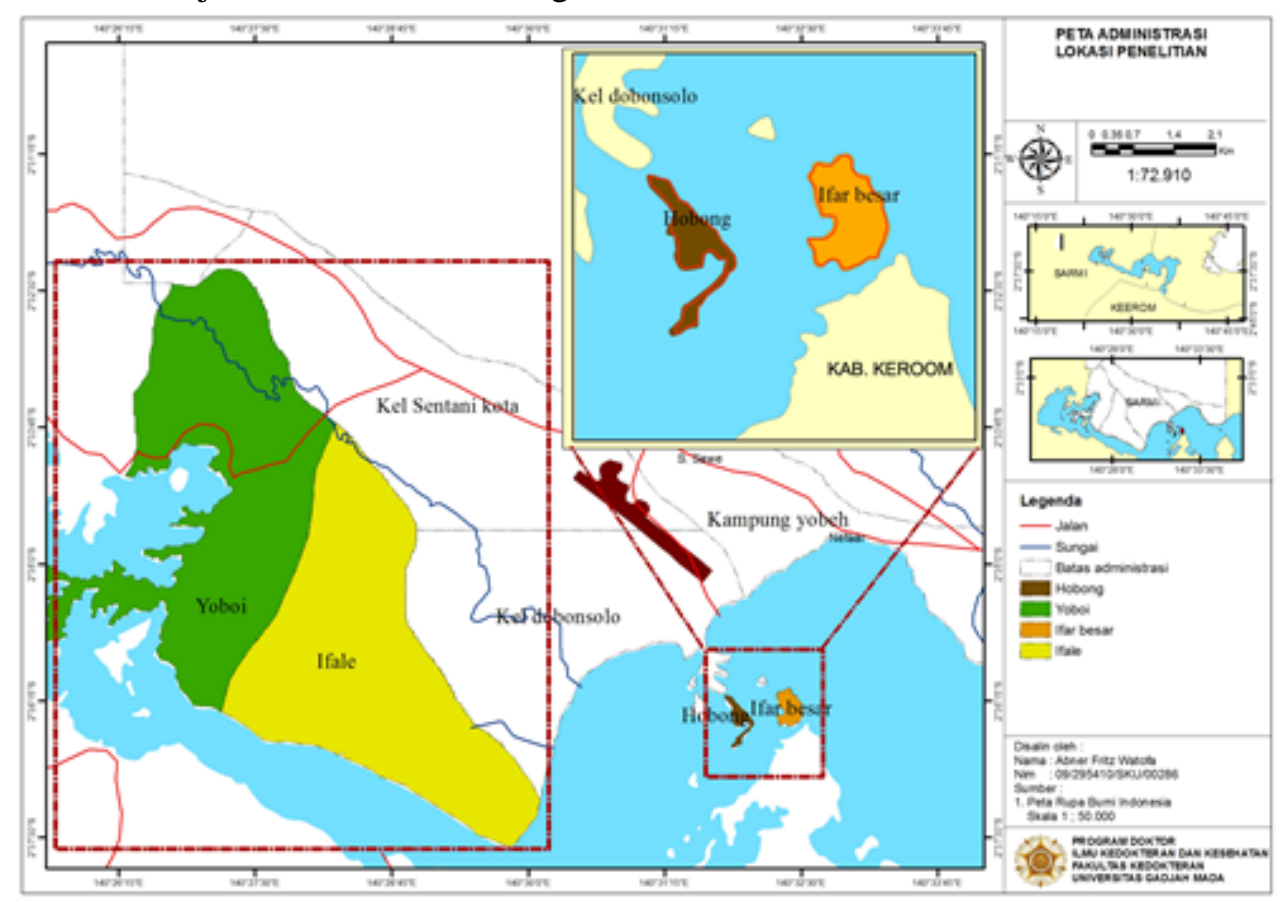

Gambar 1. Peta administrasi lokasi penelitian danau Sentani 
Tabel 1. Karakteristik responden.

\begin{tabular}{lcrr}
\hline Parameter & Kelompok & Jumlah (orang) & Persentase (\%) \\
\hline Jenis kelamin & Laki-laki & 116 & 58 \\
& Perempuan & 84 & 42 \\
& Total & 200 & 100 \\
\hline Kelompok usia ( tahun) & $\leq 20$ & 14 & 7 \\
& $21-30$ & 91 & 45,5 \\
& $31-40$ & 70 & 35 \\
& $41-50$ & 21 & 10,5 \\
& $>50$ tahun & 4 & 2 \\
& Total & 200 & 100 \\
\hline Tingkat pendidikan & & & 8,5 \\
& SD & 17 & 26,5 \\
& SMP & 53 & 58,5 \\
& SMA & 117 & 1,5 \\
& D-3 & 3 & 5 \\
& S-1 & 10 & 100 \\
\hline Pekerjaan & Total & 200 & 63,5 \\
& & & 5,5 \\
& Petani & 127 & 28,8 \\
& PNS & 11 & 0,5 \\
\hline Buruh & 57 & 5 &
\end{tabular}

Sumber : Analisis data primer, 2013

regresi logistik. Penyajian data untuk mengetahui distribusi frekuensi masing-masing variabel independen terhadap penularan penyakit malaria dianalisis dengan analisis bivariate serta uji statistik Chi-Square terhadap jawaban responden pada setiap kuesioner.

Uji statistik yang digunakan untuk menganalisis data adalah uji Chi Square dengan tabulasi silang $2 \times 2$ untuk mencari odds ratio (OR) (Thompson, 1994). Uji statistik ini digunakan untuk mendapat nilai $\mathrm{p}$ dengan tingkat kemaknaan $\mathrm{p}<$ 0,05 untuk melihat sejauh mana hubungan antara paparan (exposure) dengan kejadian malaria (outcome) digunakan nilai rasio prevalensi (RP) dengan $95 \%$ convidence interval $(\mathrm{Ci})$.

Regresi logistik kadang disebut model logistik atau model logit, dalam statistika digunakan untuk prediksi probabilitas kejadian suatu peristiwa dengan mencocokkan data pada fungsi logit kurva logistik (Ghozali, 2012). Metode ini merupakan model linier umum yang digunakan untuk regresi binomial. Seperti analisis regresi pada umumnya, metode ini menggunakan beberapa variabel prediktor, baik numerik maupun kategori. Uji regresi logistik merupakan salah satu pendekatan model matematis yang digunakan untuk menganalisis hubungan satu atau beberapa variabel bebas dengan sebuah variabel terikat dengan kategorik, misalnya sehat dan sakit.

\section{HASIL DAN PEMBAHASAN}

\section{Karakteristik Responden di Wilayah Danau Sentani}

Responden penelitian ini lebih banyak lakilaki dan kelompok usia produktif dengan tingkat pendidikan yang rendah. Profesi utamanya adalah petani. Distribusi karakteristik responden dapat dilihat pada Tabel 1.

\section{Analisis Univariat Variabel Penelitian}

Variabel penelitian ini adalah faktor risiko lingkungan fisik yang mencakup suhu, kelembaban, curah hujan, kondisi air atau $\mathrm{pH}$ air, ketinggian, penggunaan lahan, dan kondisi rumah masyarakat. Rerata suhu udara di lokasi penelitian adalah 27,3 ${ }^{\circ} \mathrm{C}$. Sementara suhu udara terendah adalah $23^{\circ} \mathrm{C}$ dan tertinggi adalah $32 \quad{ }^{\circ} \mathrm{C}$. Data suhu udara ini didukung dengan laporan mengenai suhu yang dikeluarkan oleh Badan Meteorologi dan Geofisika Papua, yakni berkisar dengan rerata $27{ }^{\circ} \mathrm{C}$. Berdasarkan laporan BMG Papua, suhu maksimum di lokasi penelitian pada siang hari adalah $32,2{ }^{\circ} \mathrm{C}$, suhu pada malam hari $23,6{ }^{\circ} \mathrm{C}$, sedangkan suhu rerata pada siang hari berkisar pada $27,6{ }^{\circ} \mathrm{C}$ biasanya terjadi pada bulan November dan Desember.

Rerata kelembaban di lokasi penelitian sebesar $81,2 \%$. Kelembaban udara di lokasi penelitian ini juga didukung hasil pengukuran kelembaban udara yang dilaporkan BMG Papua bahwa rata-rata 
kelembaban di kampung Yoboi/Kehiran sebesar $82 \%$, di kampung Hobong sebesar $81 \%$, sedangkan di dua Kampung Ifar Besar dan Ifale masingmasing sebesar $80 \%$. Kelembaban tertinggi berada di Kampung Yoboi/Kehiran yakni sebesar $84 \%$. Sementara rata-rata kelembaban di keempat lokasi penelitian adalah sebesar $80,7 \%$ hampir sama dengan kelembaban suhu yang diperoleh dengan cara melakukan pengukuran langsung yakni sebesar $81,2 \%$.

Berdasarkan data yang dilaporkan BMG Papua, kelembaban udara tertinggi di lokasi penelitian mulai pada bulan Januari sampai dengan bulan Desember 2012 berkisar antara $81-84 \%$. Kelembaban udara tertinggi terjadi pda bulan Januari dan Juni 2012. Sementara kelembaban terendah berada di Kampung Ifar Besar dan Ifale karena kedua lokasi ini berada di pulau.

Data mengenai curah hujan di lokasi penelitian diambil dari BMG Distrik Sentani pada tahun 2013 yaitu $135 \mathrm{~mm} /$ bulan dengan hari hujan yakni 13 hari/bulan atau hampir separuh dari setiap bulannya adalah hari hujan. Adapun bulan basah jatuh pada bulan Mei- Februari, sedangkan bulan kering adalah bulan Maret - April. Curah hujan per bulan mulai tahun 2010 - 2012 tertinggi terjadi pada bulan Maret yakni 471,7 mm, sedangkan yang terendah terjadi pada bulan Juni sebesar 92,4 mm.

Kondisi air atau $\mathrm{pH}$ air dalam penelitian ini diperoleh dari Dinas Kesehatan Kabupaten Jayapura tahun 2012 yang berkisar antara 6,8 7,70. pH air tertinggi berada di Kampung Yoboi/Kehiran yakni 7,70, sedangkan $\mathrm{pH}$ air paling rendah berada di Kampung Ifale yakni 6,8. Hasil pengukuran $\mathrm{pH}$ air yang dilakukan di lokasi penelitian menunjukkan hasil yang kurang lebih sama yakni berkisar antara 6,68-7,68. pH air tertinggi berada di Kampung Yoboi/Kehiran yakni 7,68 , sedangkan paling rendah terdapat di Kampung Ifale yakni 6,68. Secara keseluruhan $\mathrm{pH}$ air di lokasi penelitian bergerak antara 6,68-7,70.

Lokasi penelitian umumnya berada dalam lereng dengan kemiringan yang rendah. Kemiringan untuk wilayah dataran kering hanya sebesar $60^{\circ}$, sedangkan untuk dataran rawa hanya sebesar $10^{\circ}$. Sementara dilihat dari kemiringan Danau Sentani dari sisi utara memiliki curam kemiringan hanya $0-10^{\circ}$, sedangkan dari sisi selatan hanya sebesar $0-4^{\circ}$.

Di lokasi penelitian khususnya di tempat pemukiman masyarakat terdapat cukup luas semak belukar, lahan kering pertanian dan lahan kering campur. Sebanyak 200 orang yang berprofesi sebagai petani, 127 orang $(63,5 \%)$ di antaranya menggarap lahan-lahan yang terdapat di sekitar lokasi penelitian sebagai kebun atau ladang.
Sebagian rumah di lokasi penelitian dibangun di atas sungai atau danau. Hasil observasi yang dilakukan memperlihatkan bahwa perumahan penduduk di Danau Sentani terdiri dari dua tipe yaitu tipe rumah panggung di atas air dan tipe rumah semi permanen di atas tanah.

\section{Uji bivariat}

Uji bivariat variabel penelitian menggunakan uji Chi-Square yakni untuk mengetahui bermakna atau tidaknya faktor lingkungan fisik terhadap kejadian malaria di wilayah Danau Sentani. Untuk mengetahui bermakna atau tidaknya faktor lingkungan fisik (suhu, kelembaban, curah hujan, $\mathrm{pH}$ air, ketinggian, penggunaan lahan, dan kondisi fisik rumah) terhadap kejadian malaria dilakukan pengujia Crosstab.

Hasil pengujian cross tab yang dilakukan untuk mengetahui bermakna atau tidaknya faktor lingkungan fisik (suhu, kelembaban, curah hujan, $\mathrm{pH}$ air, ketinggian, penggunaan lahan, dan kondisi fisik rumah) terhadap kejadian malaria. Hasil penelitian memperlihatkan nilai Chi-Square sebesar 7,531 dengan $\mathrm{p}=0,006<0.05$.

Berdasarkan hasil perhitungan tersebut dapat diketahui kekuatan hubungan antara faktor lingkungan fisik dengan kejadian malaria sebesar $89 \%$. Oleh karena itu, dapat dijelaskan bahwa faktor lingkungan fisik sangat bermakna dengan kejadian malaria di wilayah Danau Sentani (sebesar 89\%). Artinya, kejadian malaria di wilayah Danau Sentani ada kaitannya dengan lingkungan fisik (suhu, kelembaban, curah hujan, $\mathrm{pH}$ air, ketinggian, penggunaan lahan, dan kondisi fisik rumah) yang ada di wilayah tersebut. Faktor lingkungan fisik (suhu, kelembaban, curah hujan, $\mathrm{pH}$ air, ketinggian, penggunaan lahan, dan kondisi fisik rumah), dapat menurunkan atau meningkatkan kejadian malaria di wilayah Danau Sentani.

\section{Uji regresi logistik}

Uji regresi logistik dilakukan untuk mengetahui bagaimana variabel-variabel independen yakni faktor lingkungan fisik dapat memprediksi variabel dependen yakni kejadian malaria. Berdasarkan hasil pengujian regresi logistik yang dilakukan memperlihatkan bahwa pengujian model I memiliki nilai $\mathrm{p}<0,05$ sehingga model 1 dapat digunakan. Berdasarkan penjelasana tersebut maka variabel faktor lingkungan fisik berpengaruh terhadap kejadian malaria di wilayah Danau Sentani. Kekuatan hubungan dapat dilihat dari nilai OR (EXP (B). kekuatan hubungan faktor lingkungan fisik yang mencakup: suhu, kelembaban, curah hujan, $\mathrm{pH}$ air, ketinggian, penggunaan lahan, dan kondisi fisik rumah (OR $=4,132)$. 


\section{Suhu}

Hasil penelitian ini memperlihatkan bahwa faktor suhu udara memiliki hubungan dengan kejadian malaria di wilayah Danau Sentani. Pengukuran suhu udara yang dilakukan selama penelitian dan juga yang dilaporkan BMG Papua menunjukkan bahwa tingkat suhu rata-rata, suhu maksimum dan suhu minimum masih dalam batasbatas suhu yang sesuai dengan kelangsungan hidup nyamuk malaria. Kesesuaian suhu udara seperti yang ada di lokasi penelitian ini, membuat nyamuk malaria dapat bertahan hidup dan berkembangbiak dengan optimal.

Suhu udara merupakan transmisi penyakit malaria (McCuthan dkk., 2004; Blanford dkk., 2013; Weiss dkk., 2014). Penyakit malaria akan berkembang seiring dengan perkembangan nyamuk. Jika suhu udara suatu wilayah masih memungkinkan bagi nyamuk Anopheles untuk hidup, maka penyakit malaria juga akan berkembang di wilayah tersebut. Suhu di wilayah Danau Sentani yang berkisar antara $23{ }^{\circ} \mathrm{C}$ sampai dengan $32{ }^{\circ} \mathrm{C}$ dengan suhu rata-rata $27,3{ }^{\circ} \mathrm{C}$, merupakan rentang suhu yang masih bisa diadaptasi oleh nyamuk malaria, karena suhu yang masih bisa diadaptasi oleh nyamuk berkisar antara $15{ }^{\circ} \mathrm{C}$ sampai dengan $40{ }^{\circ} \mathrm{C}$ (Bhattacharya, dkk., 2006).

Suhu memiliki peran yang sangat vital bagi perkembangan nyamuk. Siklus Sporogonic memerlukan waktu 9 sampai dengan 10 hari pada suhu $28{ }^{\circ} \mathrm{C}$ dan akan negatif dalam perkembangannya pada suhu di bawah $16{ }^{\circ} \mathrm{C}$ atau di atas $30^{\circ} \mathrm{C}$ (Craig dkk., 1999). Kenaikan suhu juga berdampak pada pendeknya masa inkubasi parasit sehingga mempercepat perkembangbiakan penyakit malaria (Kumar dkk., 2014). Nyamuk akan berhenti berkembang pada suhu di atas $35^{\circ} \mathrm{C}$, misalnya terjadi di Delhi saat musim panas yang suhunya di atas $40{ }^{\circ} \mathrm{C}$ atau di Bhutan $35{ }^{\circ} \mathrm{C}$ (Wangdi dkk., 2010).

Luas wilayah sebaran nyamuk juga sangat tergantung pada suhu, apalagi daerah tersebut merupakan dataran rendah yang memiliki perbukitan di dekatnya. Peningkatan suhu $1^{\circ} \mathrm{C}$ identik dengan kenaikan dataran $154 \mathrm{~m}$ (Wandiga dkk, 2010). Oleh karena itu, di wilayah Danau Sentani, sarang nyamuk tidak hanya ditemukan di sekitar danau, namun juga di lereng-lereng Gunung Cycloops.

\section{Kelembaban}

Kelembaban sebagai salah satu bagian dari faktor lingkungan fisik, juga berkaitan dengan kejadian malaria di wilayah Danau Sentani. Pengukuran kelembaban udara yang dilakukan secara langsung di lokasi penelitian dan data yang dilaporkan oleh BMG Papua menunjukkan hasil yang kurang lebih sama yang dapat dilihat dari ratarata kelembaban, kelembaban tertinggi, dan kelembaban terendah. Hasil penelitian memperlihatkan bahwa kelembaban di empat lokasi penelitian ternyata berbeda-beda satu dengan yang lain. Kampung Yoboi/Kehiran yang berada di bantaran Danau Sentani memiliki kelembaban udara yang lebih tinggi dibandingkan dengan Kampung Hobong, Kampung Ifale, dan Ifar Besar yang berada di pulau. Kelembaban yang tinggi ini dipengaruhi oleh penguapan dan keberadaan tumbuh-tumbuhan seperti pohon sagu, nipah, eceng gondok, dan lain-lain. Kelembaban juga erat kaitannya dengan curah hujan (Huang dkk., 2011).

Hasil dari penelitian ini menunjukkan bahwa rata-rata kelembaban udara di wilayah Danau Sentani berkisar antara 80,7\% - 81,2 (rata-rata hasil pengukuran dan BMG). Kelembaban udara yang masih bisa diadaptasi oleh Plasmodium falciparum and Plasmodium vivax adalah 55\% sampai $80 \%$ (Bhattacharya dkk., 2006). Kelembaban di bawah $60 \%$ akan memperpendek masa hidup nyamuk sehingga ada penurunan risiko malaria, sedangkan di atas $60 \%$ tingkat infeksi meningkat secara signifikan, bahkan risiko malaria pada kisaran $80 \%$ adalah dua kali lebih tinggi dari kelembaban $60 \%$ (Ye dkk., 2007; Tian dkk., 2008). Sementara itu, penelitian yang dilakukan oleh Suwito dan Singgih (2010) menyebutkan bahwa kelembaban dengan rata-rata tertinggi yang terjadi pada bulan Desember sebesar $84,30 \%$ dan terendah yang terjadi pada bulan Agustus sebesar 76\%, mempunyai hubungan bermakna dengan kepadatan nyamuk Anopheles per orang per malam (MBR).

\section{Curah Hujan}

Curah hujan merupakan salah satu bagian dari faktor lingkungan fisik yang sangat berpengaruh terhadap siklus nyamuk di wilayah Danau Sentani. Hasil penelitian memperlihatkan bahwa curah hujan di lokasi penelitian tergolong tinggi. Curah hujan yang tinggi ini disebabkan oleh adanya Pegunungan Cycloop. Uap air yang dibawa dari Samudera Pasifik berubah menjadi hujan di sekitar pegunungan. Curah hujan yang tinggi tersebut menyebabkan air sungai dan air danau melimpah, dan menyebabkan banyak terjadi genangan air di sekitar pemukiman masyarakat. Bahkan setiap musim hujan, wilayah ini selalu banjir. Permasalahan banjir ini erat kaitannya dengan lahan hutan yang semakin sempit akibat pembukaan lahan, perladangan berpindah yang bersifat tradisional, dan terjadinya kebakaran vegetasi pada musim kemarau (Walukow, 2011).

Rawa-rawa sagu yang selalu terisi air juga menjadi tempat perkembangbiakan nyamuk 
(breeding place) secara permanen. Akibat curah hujan yang tinggi ini, apapun yang bisa menampung air akan terisi, misalnya bekas pohon yang sudah tumbang, bekas tapak kaki hewan, bekas roda kendaraan, bekas botol minuman, dan lain-lain. Genangan air pada tempat-tempat tersebut akhirnya menjadi tempat nyamuk bertelur.

Curah hujan yang terjadi di wilayah Danau Sentani erat kaitannya dengan kejadian malaria, yaitu bila musim penghujan jumlah penderita penyakit malaria meningkat. Semakin tinggi curah hujan di lokasi penelitian, jumlah masyarakat penderita penyakit malaria juga semakin bertambah. Hasil penelitian ini sejalan dengan hasil penelitian yang dilakukan oleh Suwito dan Singgih (2010) di Lampung Selatan dan Pesawaran yang menyatakan bahwa hasil perhitungan statistik hubungan antara indeks curah hujan dengan kepadatan nyamuk Anopheles memiliki hubungan yang bermakna. Koefisien determinasi menunjukkan nilai 0,569 , artinya kepadatan nyamuk Anopheles 56,9\% disebabkan oleh curah hujan (Suwito dan Singgih 2010). Subbarao (1998) juga menyatakan bahwa curah hujan merupakan faktor dominan penyebab penyakit malaria di India.

\section{Kondisi air (pH)}

Temuan penelitian memperlihatkan $\mathrm{pH}$ air merupakan salah satu faktor yang mendukung kejadian malaria di wilayah Danau Sentani. Hasil penelitian memperlihatkan bahwa $\mathrm{pH}$ air berkisar antara 6,70-7,70, yang merupakan kadar normal untuk kehidupan larva nyamuk. Effendi (1997) menyatakan bahwa $\mathrm{pH}$ air 6,68-7,68 merupakan kadar normal yang mendukung perkembangbiakan kehidupan larva atau jentik. Penelitian yang dilakukan Soleimani-Ahmadi dkk. (2014) di Iran bagian tenggara, menyebutkan bahwa ditemukan jumlah larva Anopheles yang melimpah pada air dengan $\mathrm{pH} 7,1$ sampai dengan 8,6. Abdullah dan Merdan (1995) menyatakan bahwa larva menyukai air normal atau sedikit basa. Hasil penelitian di Ghana, Ethiopia, Sri Lanka, China dan India juga menunjukkan kesamaan bahwa larva Anopheles berkembang secara optimal pada $\mathrm{pH}$ normal atau sedikit basa (Saxena dkk., 1992; Piyaratne dkk., 2005; Kenea dkk., 2011; Kudom dkk., 2012; Liu dkk., 2012;).

\section{Ketinggian}

Ketinggian merupakan salah satu bagian daria faktor lingkungan fisik yang berpengaruh terhadap kejadian malaria di wilayah Danau Sentani. Hasil penelitian memperlihatkan bahwa lokasi penelitian cenderung berada pada dataran rendah. Pada dataran rendah, nyamuk memiliki jangkauan terbang yang cukup luas. Di samping itu, ketinggian suatu wilayah erat kaitannya dengan suhu, sehingga pada dataran rendah, suhu udara rata-rata lebih tinggi daripada dataran tinggi yang memungkinkan nyamuk lebih mudah beradaptasi dan berkembang biak serta memiliki agresifitas yang cukup tinggi.

Temuan lain yang sejalan dengan penelitian ini adalah penelitian di Tanzania yang menyebutkan bahwa pada dataran yang lebih tinggi, kepadatan nyamuk menjadi berkurang. Namun pada penelitian ini nyamuk berkurang diduga karena genangan air atau sungai juga berkurang (Drakeley dkk., 2005). Di dataran tinggi peresapan air cenderung terjadi secara cepat dan aliran air cenderung deras sehingga menyulitkan larva untuk hidup.

\section{Penggunaan Lahan}

Penggunaan lahan merupakan salah satu faktor yang mendukung kejadian malaria di wilayah Danau Sentani. Selain digunakan untuk membuat rumah, lahan di lokas penelitian juga digunakan untuk laha perkebunan, pertanian, kolam ikan, dan kandang ternak. Penggunaan lahan sebagai lahan perkebunan, pertanian, kolam ikan maupun kandang ternak sering tidak memperhatikan tata ruang yang baik. Tanah perkebunan/ pertanian sering ditelantarkan cukup lama ketika sudah panen. Kolam-kolam ikan dan kandang ternak juga tida dijaga kebersihan dan kenyamanannya.

Pemanfaatan lahan yang tidak memperhatikan tata ruang yang baik akan mempengaruhi iklim mikro misalnya perubahan suhu lokal, kelembaban, penguapan, dan cuaca lokal yang semuanya itu berhubungan erat dengan penyakit malaria (Foley dkk., 2005). Larva di lahan pertanian juga menjadi lebih cepat tumbuh menjadi nyamuk (Munga dkk., 2000).

\section{Fisik Rumah}

Kondisi fisik rumah masyarakat pada umumnya sangat sederhana karena terbuat dari bahan-bahan seperti papan bekas atau bambu sehingga ditemukan lubang-lubang pada dinding rumah. Lubang-lubang yang ada tidak dipasangi kasa, sehingga nyamuk dapat leluasa masuk ke dalam rumah dan menyerang penghuninya. Kebersihan rumah, baik di dalam maupun di luar juga tidak terawat. Banyak perkakas yang berserakan, tidak tertata, kotor, dan keadaan di dalam rumah yang pengap mengakibatkan nyamuk menyukai tempat tersebut. Di sekitar rumah terdapat tumpukan barang-barang bekas dan sampah yang berserakan. Di sekitar rumah juga terdapat genangan-genangan air, semak-semak, dan tanaman liar. Secara keseluruhan kondisi fisik rumah masyarakat baik di dalam rumah maupun di 
luar rumah, menjadi penyebab terjadinya penyakit malaria di wilayah Danau Sentani.

Hasil penelitian ini sejalan dengan penelitian di Trenggalek yang menemukan adanya korelasi yang kuat antara konstruksi rumah dengan kejadian malaria karena seluruh rumah responden tidak memiliki kasa dan langit-langit untuk mencegah nyamuk masuk ke dalam rumah (Yudhastuti, 2008). Lobang yang tidak ditutupi dengan kasa akan menyebabkan peningkatan populasi nyamuk di dalam rumah (Sintasath dkk., 2005; Ye dkk., 2006).

\section{KESIMPULAN}

Hasil pengujian statistik faktor lingkungan fisik (suhu, kelembaban, curah hujan, $\mathrm{pH}$ air, penggunaan lahan, dan kondisi fisik rumah) di wilayah Danau Sentani memiliki hubungan yang bermakna dengan kejadian malaria. Suhu, kelembaban, curah hujan, kondisi air, penggunaan lahan, dan kondisi fisik rumah saling berhubungan satu sama lain dalam mempengaruhi perkembangan nyamuk malaria yang berdampa pada kejadian malaria yang tinggi di wilayah Danau Sentani.

Pemerintah khususnya Dinas Kesehatan agar dapat memperhitungkan faktor risiko lingkungan fisik dalam mengendalikan perkembangbiakan nyamuk Anopheles, sehingga setiap perubahan lingkungan fisik ada tindakan yang sesuai. Pengendalian dan tata ruang lingkungan yang baik harus segera diatur dan dilaksanakan oleh pihak terkait, dalam hal ini Pemerintah Kabupaten Jayapura untuk mengatur lahan-lahan yang dipakai untuk pemukiman, pertanian, peternakan, maupun menjaga keberadaan hutan tetap lestari. Lahan kritis juga harus segera diperbaiki, karena akan mempengaruhi cuaca lokal di wilayah Danau Sentani yang berdampak perkembangan nyamuk semakin tinggi.

Pemerintah segera melakukan perbaikan sarana drainase dan kantong-kantong resapan air di lereng-lereng pegunungan Cycloop. Sistem drainase dan resapan air penting untuk mengurangi genangan air di permukaan tanah yang menjadi media hidup larva nyamuk. Sistem drainase dan resapan air juga bermanfaat untuk sumber penyediaan air bersih dan mencegah terjadinya banjir saat musim hujan..

\section{DAFTAR PUSTAKA}

Abdullah, M.A., dan Merdan, A.I., 1995. Distribution and Ecology of the Mosquito Fauna in the Southwestern Saudi Arabia. J. Egypt. Soc. Parasitol, 25(3):815-837.

Arsin, A.A., dan Karim, S.A., 2012. Pola Spasial Kasus Malaria dengan Aplikasi Sistem
Informasi Geografis (SIG) di Kabupaten Halmahera Tengah 2008. Jurnal Masy. Epid, 1(2):84-89

Ayomi, A.C., Setiani, O., dan Joko, T., 2012. Faktor Risiko Lingkungan Fisik Rumah dan Karakteristik Wilayah Sebagai Determinan Kejadian Penyakit Tuberkulosis Paru di Wilayah Kerja Puskesmas Sentani Kabupaten Jayapura Provinsi Papua. Jurnal Kesehatan Lingkungan Indonesia, 11(1):1-8.

Bhattacharya, S., Sharma, C., Dhiman, R., dan Mitra, A,A., 2006. Climate Change and Malaria in India. Current Science, 90:369-374.

Blanford, J.I., Blanford, S., Crane, R.G., Mann, M.E., Paaijmans, K.P., dan Schriber, K.V., 2013. Implications of Temperature Variation for Malaria Parasite Development Across Africa. Sci. Rep., 3:1300.

Craig, M.H., Snow, R.W., dan Le Sueur, D.A., 1999. Climate-based Distribution Model of Malaria Transmission in sub-Saharan Africa, Parasitology Today, 15(3):105-111.

Drakeley, C.J., Carneiro, I., Reyburn, H., Malima, R., Lusingu, J.P., dan Cox. C., 2005. AltitudeDependent and Independent Variations on Plasmodium falciparum Prevalence in Northeastern Tanzania. J. Infect. Dis. 191:1589-1598.

Effendie, M.I., 1997. Biologi Perikanan. Yayasan Dewi Sri. Bogor

Foley, J.A., DeFries, R., Asner, G.P., Barford, C., Bonan, G., dan Carpenter, S.R., 2005. Global Consequences of Land Use. Science, 309(5734):570-574.

Ghozali, I., 2012. Aplikasi Analisis Multivariate dengan Program SPSS. Badan Penerbit Universitas Diponegoro. Semarang

Huang. F., Zhou, S., Zhang, S., Wang, H., dan Tang, L., 2011. Temporal Correlation Analysis between Malaria and Meteorological Factors in Motuo County, Tibet. Malaria J., 10:54.

Kenea, O., Balkew, M., dan Gebre-Michael, T., 2011. Environment Factors Associated with Laval Habitats on Anopheline Mosquitoes (Diptera:Culicidae) in Irrigation and Major Drainage Areas in the Middle Course on the Rift Valley, Central Ethiopia, J Vector Borne Dis, 48(2):85-92.

Kudom, A.A., Mensah, B.A., dan Agyemang, T.K., 2012. Characterization of Mosquito Laval Habitats and Assessment of InsecticideResistance Status of Anopheles Gambiae Senso lato in Urban Areas in Southwestern Ghana. J. Vector. Ecol., 37(1):77-82.

Kumar, V., Mangal, A., Panesar, S., Yadav, G., Talwar, dan R., Raut, D., 2014. Forecasting Malaria Cases Using Climate Factors in Delhi, 
India: A Time Series Analysis. Malaria Res. \& Treatment, DOI:10.1155/2014/482851.

Liu, X.B., Liu, Q.Y., Guo, Y.H., Jiang, J.Y., Ren, D.S., dan Zhou, G.C., 2012. Random Repeated Cross Sectional Study on Breeding Site Characterization of Anopheles Sinensis Larvae in District Villages of Yongcheng City, People's China. Parasit Vectors, 5:58.

McCutchan, T.F., Grim, K.C., Li, J., Weiss W, Rathore D, dan Sullivan M., 2004. Measuring the Effects of an Ever-Changing Environment on Malaria Control. Infect. Immun. 72(4): 2248-2253.

Marrai, M., 2006. Faktor-faktor yang Berhubungan Dengan Dinamika Penularan Malaria Falciparum di Kecamatan Nabire. Tesis. Ilmu Kesehatan Masyarakat Program Pascasarjana UGM, Yogyakarta.

Munga, S., Minakawa, N., Zhou, G., Mushinzimana, E., Barrack, O.O.J., dan Githeko, A.K., 2000. Association Between Land Cover and Habitat Productivity of Malaria Vectors in Western Kenyan Highlands. Trop Med. Int. Health, 5(4):263-274.

Piyaratne, M.K., Amerasinghe, F.P., Amerasinghe, P.H., dan Konradsen, F., 2005. Physicochemical Characteristics of Anopheles Culicifacies and Anopheles Varuna Breeding Water in A Dry Zone Stream in Sri Langka, $J$. Vector. Borne. Dis. 42(2):61-67.

Rahardjo, M., 2003. Studi Karakteristik Wilayah Sebagai Determinan Penyebaran Malaria di Lereng Barat dan Timur Pegunungan Muria Jawa Tengah. UGM, Yogyakarta

Saxena, O.P., Kumar, M.L., Saxena, A., Sharma, M.C., dan Saxena, R.C., 1992. Study on the Physico-chemical Characteristics of Breeding Grounds in Relation to the Population density of Anopheles Stephensi. J. Commun. Dis. 24(2):109-115.

Sintasath, D., Ghebremeskel, T., Lynch, M., Kleinau, E., Bretas, G., dan Shililu, J., 2005. Malaria Prevalence and Associated Risk Factors in Eritrea. Am. J. Trop. Med. Hyg., 72:682-687.

Soleimani-Ahmadi, M., Vatandoost, H., dan Zare, M., 2014. Characterization of Larval Habitats of Anopheline Mosquitoes in a Malarious Area Under Elimination Program in the Southeast of Iran. Asian Pac J. Trop. Biomed., 4: S73-S80.
Subbarao, K.S., 1998. Anopheles Species Complexes in South East Asia. WHO, New Delhi.

Suwito, U.K.H., dan Singgih, H.S., 2010. Hubungan Iklim, Kepadatan Nyamuk Anopheles dan Kejadian Penyakit Malaria. J. Entomol. Indones., 7(1):42-53.

Thompson, W.D., 1994. Statistical Analysis of Case Control Studies, Epidemiological Rev., 16:1.

Tian, L., Bi, Y., Ho, S.C., Liu, L., dan W., Liang, S., 2008. One-year Delayed Effect of Fog on Malaria Transmission: a Time series Analysis in the Rain Forest Area of Mengla County, South West China. Malaria J., 7; 110.

Walukow, A.F., 2011. Analisis Tujuan Pengelolaan dan Kebutuhan dalam Pengembangan Danau Sentani Jayapura. Jurnal Bumi Lestari, 11(1):120-130.

Wangdi, K., Singasivanon, P., Silawan, T., Lawpoolsri, S., White, N.J., dan Kaewkungwal, J., 2010. Development of Temporal Modelling for Forecasting and Prediction of Malaria Infections using timeseries and Analysis: A Case Study in Endemic Districts of Bhutan. Malaria J., 9:251.

Wandiga, S.O., Opondo, M., Olago, D., Githeko, A., dan Githui, F.M.M., 2010. Vulnerability to Epidemic Malaria in the Highlands of Lake Victoria Basin: the Role of Climate Change/Variability, Hydrology and SocioEconomic Factors, Climate Change, 99(34):473-497.

Weiss, D.J., Bhatt, S., Mappin, B., Van Boeckel, T.P., Smith, D.L., dan Hay, S.I., 2014. Air Temperature Suitability for Plasmodium falciparum Malaria Transmission in Africa 2000-2012: A High-Resolution Spatiotemporal Prediction, Malaria J., 13:171.

Ye, Y., Louis, V., Simboro, S., dan Sauerborn, R., 2007. Effect of Meteorological Factors on Clinical Malaria Risk among Childtren: an Assesment Using Village-based Meteorological Stations and Community-based Parasitological Survey. BMC Public Health, 7:101.

Yudhastuti, R. 2008. Gambaran Faktor Lingkungan Daerah Endemis Malaria di Daerah Berbatasan (Kabupaten Tulungagung dengan Kabupaten Trenggalek), Jurnal Kesehatan Lingkungan, 4(2):9-2. 